\title{
QUESTÕes ABOLICIONISTAS EM BERNARDo GUIMARÃES
}

\author{
Abolitionist Approach in Bernardo Guimarães
}

\section{Cuestiones abolicionistas en Bernardo Guimarães}

Juliana Fillies Testa Muñoz ${ }^{1}$

\begin{abstract}
Resumo: Durante séculos, o sistema escravagista foi o principal pilar da economia brasileira. Contudo, a partir do início do século XIX, o escravismo se transforma em um símbolo de atraso econômico e moral. Dá-se, assim, inicio a um assíduo debate do qual participam intelectuais de todas as áreas. Propõe-se com esse artigo, analisar a forma como questões abolicionistas são abordadas por Bernardo Guimarães
\end{abstract}

Palavras-chave: Abolição. Bernardo Guimarães. Literatura abolicionista.

Abstract: During centuries, the slavery system had been the pillar of the Brazilian economy. As of the first decades of the nineteenth century, slavery as an institution turns into a symbol of economic and moral backwardness. An assiduous debate begins, in which intellectuals of all areas participate. We intend to analyze, in this article, the abolitionist approach in Bernardo Guimarães.

Keywords: Abolition. Bernardo Guimarães. Abolitionist literature.

Resumen: Durante siglos, el sistema esclavista fue el principal pilar de la economía brasileña. No obstante, a partir del inicio del siglo XIX, el esclavismo se transforma en un símbolo de atraso económico y moral. Empieza, así, un asiduo debate del cual participan intelectuales de todas áreas de Conocimiento. Proponemos, con este artículo, el análisis de la forma en que algunas cuestiones abolicionistas son abordadas por Bernardo Guimarães.

Palabras clave: Abolición. Bernardo Guimarães. Literatura abolicionista.

1 Universidade de Colônia, Alemanha.

\begin{tabular}{|lrllll}
\hline TEL & IRATI (PR)/Ponta Grossa (PR) & v.6 N.1 & P. 95-108 JAN./Jun. 2015 & E-ISSN: 2177-6644 \\
DOI $.10 .5935 / 2177-6644.20150008$ & & & \\
\hline
\end{tabular}


ESCRAVISMO E CAMPANHA ABOLICIONISTA No Brasil

Durante mais de 300 anos, aproximadamente quatro milhões de africanos foram trazidos ao Brasil e submetidos ao trabalho escravo (COWLING, 2010. p. 285). Inicialmente, foram empregados na cultura açucareira do Nordeste. Nos séculos XVII e XVIII, foram de utilidade na mineiração de ouro e de diamantes em Minas Gerais. A importação em massa de escravos, no entanto, só tem inicio na primeira metade do século XIX, com a expansão da cultura cafeeira no Vale do Paraíba e no Oeste Paulista. A demanda por mão-de-obra havia crescido consideravelmente e a importação em massa de escravos surge como uma medida eficaz para solucionar o problema (VENTURA, 1987, p. 65). O trabalho escravo, portanto, representou durante anos a principal coluna da economia brasileira que, nessa época, tinha como base a produção agrícola. Notase, desse modo, que a principal motivação da prática escravagista era de cunho econômico. No entanto, buscou-se legitimar a instituição da escravidão na América Latina por meio de um discurso religioso. Os africanos seriam, segundo a exegese branca dos textos bíblicos, descendentes de Cam, um dos filhos de Noé (Cf. ALLPORT, 1971, p. 11). De acordo com o relato em Gênesis, os descendentes de Cam haviam sido condenados por Noé a serem eternamente escravos dos seus irmãos (GN, 9,25). Seguindo essa lógica, os negros, devido a sua 'ascendência', estariam predestinados à escravidão. Pecadores e malditos por natureza, os africanos só poderiam aspirar a salvação da sua alma, a qual seria alcançada através da sua conversão ao cristianismo. A escravidão, portanto, era apresentada como uma missão evangelizadora, através da qual os africanos alcançariam o perdão de Deus e a absolvição dos seus pecados (Cf. OLÍMPIO, 2007, p. 277; VIGNAUX, 2002, p. 92). Os escravagistas também buscaram justificar o sistema através de um discurso civilizatório e humanitário. A escravidão e o iminente contato com a raça superior proporcionaria ao negro africano uma experiência única com o mundo civilizado. Através dela, os escravos alcançariam, ainda que parcialmente, a civilização, libertando-se do seu natural barbarismo (Cf. ORTIZ, 1916, p. 101). Durante séculos, poucas vozes se levantaram para contestar essas 'inquestionáveis verdades' ou revogar o sistema. Esse quadro começa a mudar no Brasil somente no inicio do século XIX, como consequência de um movimento anti-escravagista mundial ao qual diversos intelectuais brasileiros aderiram. O movimento iluminista e a Revolução Francesa desencadearam a formação de grupos e de ideais liberais e humanitários. Esses pleiteavam o fim imediato da escravidão. Como consequência, a Inglaterra e a França, já no inicio do século XIX, decidem decretar a abolição da escravidão em suas colônias (Cf. MARTINS, 1977, p. 24; RABASSA, 1965, p. 84). A partir de então, a questão abolicionista começará a ser colocada em debate também pela elite brasileira (Cf. SAYERS, 1956, p. 65).

No Brasil, os primeiros sinais de uma abertura para a ideia de uma abolição gradual fazem-se visíveis já na segunda década do século XIX. Sob pressão britânica, o governo brasileiro concorda, em 1826, em abolir o tráfico negreiro no decorrer dos seguintes três anos. Desse modo, proclama-se em 1831 a Lei Regencial, a qual tornava ilegal o tráfico e determinava a libertação de todos os africanos que chegassem a terras brasileiras a partir de então. Essa lei, contudo, foi amplamente infringida graças à indulgência das autoridades que permitiram que o tráfico continuasse 
ilegalmente (Cf. MOURA,1997, p. 10). Como observa Ventura,

[...] cria-se uma curiosa situação de disparidade entre o Brasil legal, que havia extinguido frente ao estrangeiro o vergonhoso comércio de africanos, e o Brasil real, em que os escravos eram abertamente importados e vendidos. $\mathrm{Na}$ verdade, a manutenção do tráfico de escravos se torna uma das questões fundamentais da jovem nação brasileira que procura afirmar a sua independência frente às pressões externas, prosseguindo na importação de africanos, ao mesmo tempo que decretava oficialmente o seu fim (VENTURA, 1987, p. 72)

Os defensores do sistema escravagista alegavam que a abolição da escravidão não era viável em um país como o Brasil. Em vez de aproximá-lo dos países mais desenvolvidos, ela conduziria o Brasil gradativamente à ruina e impossibilitaria o seu posicionamento no contexto internacional. Para os escravocratas, a economia brasileira dependia do braço escravo e não poderia abster-se dele. Nota-se, assim, que após a proclamação da Lei Regencial o tráfico negreiro se torna ainda mais ativo. Pesquisas demonstram que, entre 1830 e 1850 , entram um total de cerca de 700.000 africanos no Brasil (Cf. BOSI, 1992, p.196). O tráfico de africanos só é eficazmente extinguido no ano de 1850, com a promulgação da Lei Eusébio de Queiroz (Cf. MOURA, 1997, p.10).

Abolido o tráfico negreiro, os reformistas brasileiros puderam concentrarse na luta contra a instituição da escravidão no país. Como observa Sayers,

[...] the history of Brazil from that date until the signing in 1888 of the Lei Áurea of emancipation is to a large extent that of the struggle against slavery (Cf. SAYERS, 1956, p. 85).
Principalmente depois da Guerra do Paraguai, em 1870, intensifica-se a campanha contra o sistema escravagista no país. Segundo Skidmore, foi justamente a Guerra do Paraguai que fez os brasileiros repensarem a nação. Ela havia exigido o recrutamento de muitos escravos que se tornaram valiosos soldados para exército e obtiveram a sua liberdade. Contraditoriamente, esses mesmos ex-escravos, como integrantes do exército, têm a tarefa de capturar os escravos fugidos. Diversos oficiais militares começam a reconhecer as vantagens da libertação dos escravos e aderem às ideias abolicionistas $\mathrm{e}$ liberais (Cf. SKIDMORE, 1974, p. 8). Para a mesma época, é formado o Partido Liberal Radical a partir do qual surge, em 1870, o Partido Republicano. Os republicanos eram abolicionistas e pleiteavam a substituição radical ou progressiva do trabalho escravo pelo livre. A mão-de-obra escrava deveria ser substituída pelo braço imigrante. De fato, a partir deste decênio, a imigração europeia começa a crescer exponencialmente e já em 1880 entrava no país meio milhão de imigrantes (Cf. BOSI, 2006, p. 164).

A realidade era que o sistema escravagista se tornara insustentável. Os Estados Unidos abolira a escravidão em 1865, e o Brasil e Cuba (que para essa época ainda era colônia espanhola) eram os únicos países do hemisfério leste a manter o sistema escravagista. Isso colocava o Brasil, já independente, em uma posição delicada. A escravidão se tornava símbolo de atraso, de barbárie, e afastava o país das nações consideradas civilizadas e modernas. A necessidade de debater o futuro do país e abolir a escravidão é visível e concreta na fala de José do Patrocínio, para quem

[...] só há atualmente neste país uma questão séria: é a abolição da escravidão. 
Para ela convergirão fatalmente pelo impulso da propaganda, como pela resistência dos oposicionistas, todas energias vivas do país ${ }^{2}$ (PATROCINIO, 1996, p. 43).

A campanha abolicionista no Brasil é liderada por Patrocínio, por Tavares Bastos e por Joaquim Nabuco. Esses apoiavam a abolição imediata que deveria ser alcançada por meio de um decreto legal e não através de um levante popular (Cf. VENTURA, 1987, p. 129; NABUCO, 2000, p. 12). É provável que os integrantes da elite temessem uma revolta de escravos como a que havia ocorrido anos antes no Haiti, a qual levou não só a abolição da escravidão como ao assassinato em massa dos senhores brancos (Cf. LÜSENBRINK, 1994, p.151).

Na segunda metade do século XIX, o discurso religioso e humanitário, que por muitos anos havia legitimado a escravidão, perdia vigor. A indispensabilidade da abolição não estava mais em debate e sim a forma de emancipação a ser adotada. O debate se dividia em dois polos opostos: abolição gradual versus abolição imediata. Os proprietários de escravos alegavam que lhes faltava mãode-obra e que não podiam dispensar os escravos enquanto não houvesse suficientes trabalhadores livres que pudessem suprir a demanda por braços na lavoura cafeeira. Argumentavam, assim, que

[...] a escravidão era um mal necessário e o braço escravo insubstituível na situação em que se achava o país. Atingir o sistema era acabar com a prosperidade nacional, condenar à desorganização a lavoura, principal base da riqueza do país (COSTA, 1997, p. 414).
Além do discurso financeiro, os senhores de escravos se empenharam em justificar o regime com base em ideologias raciais deterministas em voga. Essas teorias racistas buscavam 'provar' que os negros (e por consequência, também seus descendentes mulatos) eram geneticamente inferiores aos brancos. Assim, o discurso religioso sobre a suposta superioridade branca é substituído por uma argumentação científica. Eivados de preconceito, despeito a ascensão gradual de mulatos na sociedade imperial, muitos integrantes da elite brasileira oitocentista acreditavam na necessidade de preparar os escravos para a liberdade (Cf. COSTA, 1997, p. 413). José de Alencar foi um dos principais opositores da Lei do Ventre Livres, porque acreditava que era necessário

[...] esclarecer a inteligência embotada, elevar a consciência humilhada para que um dia, no momento de concederlhes a liberdade possamos dizer: vós sois homens, sois cidadãos. Nós vos remimos não só do cativeiro como da ignorância, do vicio e da miséria, da animalidade em que jazeis ${ }^{3}$ (ALENCAR apud COSTA, 1997, p. 420).

Em contrapartida, aqueles que pregavam a abolição imediata da escravidão, argumentavam que, além de representar "[...] a shameful anachronism" (SKIDMORE, 1974 , p. 18), a escravidão era nociva ao desenvolvimento financeiro do país. Ao contrário dos proprietários de escravos, os abolicionistas alegavam que manter o trabalho escravo ameaçava o progresso econômico do Brasil e devia ser incontinenti substituído pela mão-de-obra livre. De outro modo, o regime escravagista levaria o país à ruina:

3 Discurso feito em sessão de 31 de Julho de 1871. 
Aí se verificaria como a escravatura, longe de ser uma garantia da produção, é hoje uma grande ameaça ao seu desenvolvimento.

Hoje ninguém mais pode impedir que haja entre o senhor e o escravo uma suspeição, que se há de aumentar dia a dia. O senhor pelo temor da abolição, o escravo pela convicção de que a sua posição não tem base nem na lei, nem na natureza; tratarão ambos de se prejudicar o mais possível. O senhor buscará extrair da mina negra todo o ouro possível, sem pensar no prejuízo, que resultará de exauri-la. O escravo buscará por todos os meios produzir o menos que lhe for possível.

O prejuízo de tal luta não será, porém sofrido unicamente pelos dois lutadores, mas pela sociedade inteira. $\mathrm{O}$ resultado será em definitivo ofenômeno que querem conjurar pela inércia - a diminuição da produção. A este fenômeno deve-se acrescentar que a diminuição não traz nenhum proveito para o país, porque não é a iniciação de uma época nova, mas o gasto imprevidente do sistema de trabalho ${ }^{4}$ (PATROCİNIO, 1996, p. 26).

A escravidão era vista pelos abolicionistas, portanto, como uma “[...] instituição fóssil” (NABUCO, 2000, p. 48) que afastava o Brasil da civilização e prejudicava o seu desenvolvimento econômico, porém também moral. Considerada outrora natural e benevolente, a escravidão passa a servista como cruel, injusta e contrária aos conceitos e deveres cristãos. Ela perverte os hábitos e costumes da sociedade e passa a ser considerada "[...] um 'cancro' ou infecção moral que ameaçaria os fundamentos da civilização nos trópicos". (VENTURA, 1987, p. 54). Acreditava-se que a escravidão perverteria os escravos, levandoos a cometerem crimes contra os seus senhores. Essa é uma temática abordada pelo escritor Joaquim Manuel Macedo, quem em

4 Publicado na Gazeta de Noticias em 6. Set. 1880.
1869 escreve o romance As vítimas algozes. O autor narra a história de uma família que, não concedendo a liberdade ao escravo Simeão, corrompe o seu espírito e acende o seu ódio e desejo de vingança. Todos são vítimas. $\mathrm{O}$ escravo cruel por ter sido corrompido pelo sistema (Macedo nos conta que a malvadeza do personagem não era ingénita) e a família escravagista, que mesmo tratando seus escravos com 'dignidade', se vê destruída por meio das atuações maléficas do escravo Simeão (MACEDO, 2014). Para Nabuco, é natural que exista, por vezes, conflitos entre os escravos e seus senhores e que os cativos se sintam tentados a praticar crimes, pois, segundo o estadista, "[...] a escravidão é um estado violento de compressão da natureza humana" (NABUCO, 2000, p.12).

Com as vozes contra a escravidão tornando-se cada vez mais fortes e o número de fugas e formações de quilombos aumentando velozmente, o governo brasileiro reconhece a urgência de anunciar um fim, se não imediato, ao menos gradual, da escravidão. A proibição do tráfico negreiro havia sido de grande importância para o desenvolvimento da campanha abolicionista no Brasil. Ela não determinava, porém, um fim fatual da escravidão no país, nem imediata, nem progressiva. É somente com a promulgação da Lei do Ventre Livre, em 1871, que são tomadas medidas reais para que a escravidão fosse, dentro de um determinado tempo, abolida. A Lei do Ventre Livre garantia a liberdade a todos os filhos de mães escravas, ao completarem 21 anos, que nascessem a partir desta data (FERREIRA, 2010, p. 53). Em 1885 decreta-se a Lei dos Sexagenários, a qual, segundo Moura, demonstra o grande poder dos escravocratas. Essa lei concedia liberdade aos escravos que completassem 60 anos que, no entanto, deveriam permanecer em cativeiro até os 65 anos como forma de 
indenização ao seu senhor (MOURA, 1997, p.15). Para Ferreira essa lei foi um “[...] mecanismo de manobra para assegurar a falsa libertação de escravos pelos seus senhores" (FERREIRA, 2010, p. 53). Apesar de a lei conceder a liberdade somente a escravos em uma faixa etária menos produtiva, ela levou um ano para ser aprovada (FERREIRA, 2010, p. 53). A Lei Áurea, a qual decretava o fim absoluto da escravidão no Brasil, é proclamada em 1888, quando a imigração europeia já tinha alcançado elevados números em São Paulo e nas províncias do Sul (BOSI, 1992, p. 199). O principal argumento dos escravocratas, isto é a falta de mão-de-obra para a lavoura, já não tinha mais vigor.

\section{A questão abolicionista em BERNARdo Guimarães}

A literatura pode ser considerada um campo fértil para a análise das ideias e conceitos que circularam em um determinado período histórico. França observa que no século XIX, o texto literário desempenhava uma função pedagógica. Cabia aos escritores da época

[...] colaborar para a edificação de alguns mitos nacionais, divulgar a história e a geografia pátria, contribuir para a singularização da língua brasileira e, sobretudo, moralizar os leitores (FRANÇA, 1998, p. 71).

Partimos, portanto, da premissa de que os escritores abolicionistas não somente escrevem dentro de um contexto histórico e são influenciados por ele, como também se posicionam e comentam os conceitos em voga na sociedade em que vivem. Destarte, procuram contribuir para a educação moral do leitor. A análise, portanto, de obras que retratam o meio social no século XIX, como A escrava Isaura e Rosaura: a enjeitada de Bernardo Guimarães, pode contribuir positivamente para um melhor entendimento do movimento abolicionista no Brasil. Essas obras podem ser analisadas como fontes históricas, pois deixam transparecer as ideias vigentes no século XIX em torno da escravidão.

Bernardo Guimarães é considerado o pai da novelística sertaneja e um dos principais escritores brasileiros do século XIX. Nasce em 1825 em Ouro Preto e cresce em Uberaba. Em 1847 matricula-se na Faculdade de Direito em São Paulo e convive com Álvarez de Azevedo e Aureliano Lessa. Em Goiás trabalha como juiz municipal, regressando em 1867 a sua cidade natal, onde passa a ensinar Retórica, Poética, Latim e Francês (MASSAUDE, 1977, p. 180). Publicou poemas e romances e ficou mais conhecido pela obra A escrava Isaura (1875), que teve anos depois adaptação para o cinema e para a televisão.

O romance narra a história de Isaura, uma escrava aparentemente branca, que sofre sob o jugo de um senhor devasso e cruel, chamado Leôncio. Sem muita saída, sempre exposta às malvadezas do seu senhor que sente por ela uma paixão avassaladora, a pobre cativa foge com a ajuda de seu pai para Recife onde conhece Álvaro. O jovem e Isaura se apaixonam perdidamente um pelo o outro. Superadas todas as dificuldades iniciais, Álvaro liberta a sua amada e se casa com ela. Observamos, assim, que o romance apresenta todas as características da narrativa romântica: um mocinho e uma mocinha branca que veem o seu amor ameaçado por um vilão que faz tudo por ver esse amor interrompido. A originalidade da obra, no entanto, está no fato da protagonista ser uma cativa, e uma cativa com todos os dotes (ou até mais) de uma dama da corte. Isaura não somente tem a tez como o marfim, lisa como mármore polido (Cf. GUIMARÃES, 1981, p.11), ela havia também recebido uma educação “[...] como 
não tiveram muitas ricas e ilustres damas" (GUIMARÃES, 1981, p.13). É justamente essa singularidade da protagonista, a sua apresentação como uma escrava atípica, que faz a obra, na opinião de alguns estudiosos, decair na sua natureza abolicionista. Segundo Carvalho, o ponto questionável de Bernardo Guimarães é ter dado mais importância à situação pessoal de Isaura "[...] do que discutir a própria escravidão em que não só ela se encontrava, mas os negros em sua imensa maioria" (CARVALHO, 2006, p. 61).

De fato, tem-se a impressão de que Bernardo critica a manutenção de Isaura em cativeiro, mas não a dos negros em geral. "Uma tão boa e interessante criatura não nasceu para ser escrava" (GUIMARÃES, 1981, p. 18), afirma Malvina, a esposa de Leôncio. Em outra ocasião, diz também que Isaura “[...] é bonita demais para mucama." (GUIMARÃES, 1981, p. 33). Essa ideia de que uma jovem tão bela e educada não pertence ao cativeiro, parece ser comum a basicamente todos os personagens $\mathrm{da}$ trama. Também Álvaro se mostra indignado com a situação em que se encontra Isaura e promete "[...] dar-lhe na sociedade o elevado lugar que por sua beleza, virtudes e talentos, lhe competia" (GUIMARÃES, 1981, p.126). A oposição negra-escrava e branca-escrava faz-se evidente até mesmo na fala do mulato André, quem se compadece da situação da pobre cativa branca que é tratada como uma “[...] negra da cozinha” (GUIMARÃES, 1981, p.109). O lugar de Isaura não é entre os negros. O lugar de negros é na cozinha, na senzala.

Uma situação similar encontramos em Rosaura: a enjeitada, publicada em 1883. Nesse romance é retratada a história de Adelaide e Conrado que, como fruto do amor proibido, dão vida a pequena Rosaura. Conrado, de família humilde, é impedido de casar-se com a amada, filha de uma escrava forra ao nascer e de um major eivado de preconceitos raciais e de classe. Adelaide consegue ocultar a gravidez do pai e, com a ajuda da fiel escrava Lucinda, dá a luz a uma menina que depõe na porta de uma vizinha com a fama de caridosa e justa. A recém-nascida é dada por morta e vem a ser revendida anos mais tarde como escrava à própria mãe. Rosaura, agora com 14 anos, bela e clara, começa a sofrer com a perseguição do seu novo senhor, o marido de Adelaide. A verdade vem à tona quando Lucinda, já desconfiada, indaga Rosaura sobre a sua origem. O marido e o pai de Adelaide falecem após a notícia e ela, finalmente, fica livre para casar-se com Conrado.

Rosaura é uma escrava branca, injustamente em cativeiro, que sofre com a paixão do seu senhor. A denúncia de Bernardo, também nesta obra, parece estar relacionada à cor das personagens mantidas em cativeiro. Adelaide, ainda sem conhecimento da origem de Rosaura, se compadece da situação da pobre menina:

Até faz pena ver no cativeiro uma menina tão mimosa. Se ela for boa mesmo, como parece, hei de tratá-la com todo o carinho, mais como uma companheira, uma irmã de meus filhos, do que como escrava; e até, se for possível, o meu desejo é darlhe a liberdade. Uma criatura tão bela e interessante não nasceu para o cativeiro (GUIMARÃES, 2005, p. 125).

Assim como Isaura, Rosaura não pertence ao cativeiro porque não apresenta as características físicas e morais de uma escrava 'ordinária'. As heroínas desses romances são belas, boas e interessantes demais para serem cativas. A pertinência à escravidão de outras personagens escravas, embora fieis e boas como Lucinda, não é colocada em debate. Analisando, porém, a fala de outros 
personagens, o tom abolicionista dessas obras e a posição de Bernardo a respeito se concretiza e se evidencia.

De fato, os romances A escrava Isaura e, sobretudo, Rosaura: a enjeitada não podem ser comparados a uma obra como A Cabana do Pai Tomás, da americana Harriet Beecher Stowe ${ }^{5}$, no referente ao seu apelo abolicionista. Não obstante, o autor tematiza em ambas as obras aspectos centrais da argumentação escravocrata e busca, como veremos adiante, descontruir a legitimação ideológica do sistema escravagista. Assim fazendo, Bernardo Guimarães instrumentaliza a literatura visando a transformação da estrutura social da sociedade oitocentista.

A escravidão, como apontamos, foi durante séculos justificada com base em um discurso religioso. Deus teria destinado a 'raça' branca a governar sobre as demais. Em Rosaura: a enjeitada, o autor contesta essa ideologia e afirma que somente a cobiça (Cf. GUIMARÃES, 2005, p.105) do homem pode ser responsabilizada pela instituição que por séculos privou grande parte da população mundial não somente de liberdade como de dignidade. Em A escrava Isaura, algumas escravas debatem sobre o que seria 'melhor', o trabalho no campo ou na casa grande. Depois de levantada a questão, a negra Joaquina conclui:

Qual, minha gente! - ponderou a velha crioula - tudo é cativeiro. Quem teve a desgraça de nascer cativo de um mau senhor, dê por aqui, dê por acolá, há de penar sempre. Cativeiro é má sina; não foi Deus que botou no mundo

5 Uncle Tom's Cabin (1852) é considerado um romance de central importância para o desenvolvimento do abolicionismo nos Estados Unidos. A obra narra os sofrimentos do escravo Uncle Tom, vendido por seu proprietário a um inescrupuloso traficante. Após encontrar no sul uma família que lhe trata de forma benevolente, o cativo é novamente vendido, encontrando a morte sob o chicote do novo senhor. semelhante coisa, não; foi invenção do diabo (GUIMARÃES, 1981, p. 39).

Dois aspectos parecem de relevância no excerto citado: o primeiro é a asserção tudo é cativeiro. Não era suficiente pleitear por um melhor tratamento do escravo, por leis que de alguma forma os protegessem do descontrole e da violência de um mau senhor e humanizasse a instituição. O escravo, concebido como objeto e propriedade, estaria sempre exposto ao desejo ganancioso de maximização de lucros do seu senhor. Portanto, a escravidão é para o cativo sempre uma sina, uma desgraça. Somente a sua libertação poderia garantir que ele não sofresse com os abusos e com o maltrato do proprietário. O segundo é a inversão feita por Guimarães respeito à origem da escravidão. Ao contrário do propagado pelos escravocratas, o escravismo não seria um ato cristão, um por em prática dos mandamentos católicos, e sim uma invenção do diabo. Seguindo essa lógica, os senhores de escravos não estariam atuando conforme a religião de esses exigia, ao contrário, estariam agindo em contra dela, compactuando com uma prática advinda do demônio.

Esse aspecto é abordado também, ainda que brevemente, em Rosaura: a enjeitada. Nesse romance, Bernardo dá voz ao jovem Carlos que, profundamente apaixonado por Rosaura, expressa a sua indignação com a existência da instituição da escravidão. Também para ele, a escravidão não pode ser considerada a expressão da vontade divina:

És escrava por um capricho da sorte; Deus te fez livre, porque Deus não permite a escravidão. Nasceste escrava, mas eu te farei livre, porque é um insulto feito à natureza, à humanidade, ao próprio Criador conservar na escravidão um anjo, como tu és (GUIMARÃES, 2005, p. 106). 
Nesse trecho Bernardo vai além de desconstruir o discurso religioso para afirmar os direitos igualitários entre os homens. Deus não permite a escravidão, quem a permite é a sociedade. Liberdade não é algo que deve ser concedido ou privado, é uma condição inata de todos os seres humanos, indiferente da cor de pele. Assim fazendo, o autor desmantela todo um discurso classista que determina antecipadamente a posição social dos indivíduos, embasada no histórico familiar. Fazendo das escravas as heroínas dos seus romances, Bernardo busca demonstrar que a escravidão não pode ser justificada mediante uma suposta superioridade racial do branco, visto que as mulatas apresentadas, em todos os aspectos, lhes excedem em mérito aos seus senhores. Desse modo, Bernardo inverte os valores e a hierarquia social vigente, colocando escravos e senhores sobre o mesmo escalão de comparação. Ainda mais evidente, faz-se a crítica à distinção de classes na fala do excêntrico Álvaro, o mocinho de A Escrava Isaura. Sobre a cena na qual Isaura é desmascarada (ninguém no baile havia suspeitado da sua origem), o abolicionista afirma:

Parece que Deus de propósito tinha preparado aquela interessante cena, para mostrar de um modo palpitante quanto é vã e ridícula toda a distinção que provém do nascimento e da riqueza, e para humilhar até o pó da terra o orgulho e fatuidade dos grandes, e exaltar e enobrecer os humildes de nascimento, mostrando que uma escrava pode valer mais que uma duquesa (GUIMARÃES, 1981, p. 90).

O personagem despreza todas as formas de distinção social e os privilégios de classe. Ridicularizando as distinções advindas do nascimento e da riqueza, ele diminui a importância dos valores materiais e chama a atenção para os valores internos. Desse modo, Bernardo faz uma crítica à sociedade superficial que divide os seus habitantes em mais e menos importantes, de acordo com a sua posição social.

Para Álvaro, a lei é errônea e preconceituosa, pois "[...] só vê no escravo a propriedade” (GUIMARÃES, 1981, p. 93), quando deveria "[...] proteger a inocência desvalida contra a prepotência, [...] amparar o infortúnio contra uma injusta perseguição". (GUIMARÃES, 1981, p. 93). Em outras palavras, a lei é a expressão jurídica do pensamento classista da sociedade: o que vale é a aparência, a posição social e econômica. Ela protege os poderosos e desampara os necessitados. Álvaro, apesar de ter estudado direito,

[...] aprazia-se mais na indagação das altas
questões políticas e sociais, [...], do que
em estudar e interpretar leis e instituições,
que [...], em sua opinião, só tinham por
base erros e preconceitos os mais absurdos
(GUIMARÃES, 1981, p. 63).

O herói é descrito pelo narrador como "[...] liberal, republicano e quase socialista" (GUIMARÃES, 1981, p. 63), não podendo deixar de ser, obviamente, abolicionista. O personagem representa o futuro e é, portanto, antagonista do algoz Leôncio, que simboliza o ultrapassado, ainda que vigente, sistema escravagista. Para Álvaro,

A escravidão em si mesma já é uma indignidade, uma úlcera hedionda na face da nação, que a tolera e protege. Por minha parte, nenhum motivo enxergo para levar a esse ponto o respeito por um preconceito absurdo, resultante de um abuso que nos desonra aos olhos do mundo civilizado (GUIMARÃES, 1981, p. 93).

Esse trecho remete a um dos principais argumentos da campanha abolicionista 
no século XIX. A escravidão era “[...] uma mancha de Caim que o Brasil traz[ia] na fronte" (NABUCO, 2000, p. 23), ela apartava a nação da civilização, da modernidade, da Europa, condenando o país ao eterno retrocesso. O Brasil precisava livrar-se dessa úlcera hedionda que ameaçava o futuro do país. Essa é a mensagem que Bernardo, através do seu personagem, busca passar para seus leitores. O biógrafo, Armelim Guimarães, opina que essa era a intenção de Bernardo com o romance A Escrava Isaura: combater a escravidão de forma eficiente. As ideias abolicionistas tinham que chegar ao conhecimento de todos:

Fará um romance. Será assim uma campanha perdurável. Disfarçar-se-á sua obra numa história comovente, emocionante, impressionável. Debaixo da emoção porá disfarçadamente o zaguncho do humanitarismo. Será uma estratégia altruística. Qual remédio dosado em água açucarada, seu novo livro há de ser lido pelos fazendeiros inclementes e por toda orgulhosa família do fero senhor. [...] Em vez de antipática e repelida coluna de jornal combativo, de uma existência de poucas horas e de destino, às vezes, indigno, constituirá manual de cenas embevecedoras, encadernado, marcado com folha de malva, lido em voz alta pela ilustrada sinhazinha ou nhanhã, no serão familiar da varanda ou do copiar, à curiosa assistência de analfabetos, os escravos, as mucamas, os muladeiros, o capitãodo-mato, o feitor... (GUIMARÃES, 1985, p.159). [Grifos no original]

As ideias abolicionistas não podiam, porém, permanecer no plano teórico, na fala de um personagem. Era necessário mostrar para o público leitor que a mudança era viável e vantajosa. Álvaro tinha que ser apresentado como uma força motriz de transformação da ordem social vigente:
Seja eu embora o primeiro a dar esse nobre exemplo, que talvez será imitado. Sirva ele ao menos de um protesto enérgico e solene contra uma bárbara e vergonhosa instituição(GUIMARÃES, 1981, p. 93).

Por isso, faz-se necessário que Álvaro emancipe os seus escravos e seja exitoso nisso. Álvaro tem um plano: ele não concede a liberdade aos seus escravos e os exonera do trabalho, deixando-os desamparados. O herói organiza uma espécie de colônia onde os ex-escravos podem continuar a exercer as suas atividades laborais sob a direção de um supervisor de confiança. Os libertos não seriam, assim, entregues a si mesmos, mas seriam inseridos na sociedade como importantes agentes no desenvolvimento da economia. O medo - obviamente fundamentado no preconceito racial - de que uma vez libertos, os escravos, sem o devido preparo, se entregariam a marginalidade, era compartido por muitos integrantes das altas classes sociais no Brasil. O narrador em A Escrava Isaura nos revela, porém, que da medida tomada por Álvaro

[...] podiam resultar grandes vantagens para os libertos, para a sociedade, e para o próprio Álvaro. A fazenda lhes era dada para cultivar, a título de arrendamento, e eles sujeitando-se a uma espécie de disciplina comum, não só preservavamse de entregar-se à ociosidade, ao vício e ao crime, tinham segura a subsistência e podiam adquirir algum pecúlio, como também poderiam indenizar a Álvaro do sacrifício, que fizera com a sua emancipação (GUIMARÃES, 1981, p. 63).

Bernardo, através da ação de Álvaro, expõe nesse excerto um modelo a ser seguido. Alguns argumentos dos escravocratas contra a abolição são aqui abordados e desconstruidos. Os ex-escravos não se perderiam no crime e na 
ociosidade porque permaneceriam integrados no trabalho antes praticado. Seguiriam sendo 'disciplinados' e aprenderiam a administrar o dinheiro adquirido através do esforço. Além disso, a abolição não representaria uma diminuição do patrimônio para o proprietário, pois os ex-escravos, através do seu trabalho, indenizariam o seu senhor pelo dinheiro investido na sua aquisição. $\mathrm{O}$ autor expõe, assim, as vantagens do trabalho livre e assalariado.

A libertação dos escravos é, portanto, um ato de prudência que não levará o proprietário emancipador à ruina financeira, ao contrário, esse aumentará as suas riquezas. Os benefícios econômicos da emancipação se evidenciam ainda mais se comparados os personagens Álvaro e Leôncio. O escravocrata, descrito como um homem de muito pouca cultura, a pesar das facilidades que a vida lhe proporcionou, mantem os seus escravos em cativeiro e gasta o que tem e o que não tem na busca de Isaura, a escrava fugida. A sua humilhação é completa quando Álvaro, dez vezes mais rico, aparece na fazenda do malfeitor, e declara ter adquirido todos os seus bens, dados como garantia aos comerciantes locais pelos empréstimos e serviços feitos. Temos, assim, dois exemplos de administração de fortuna, uma embasada no trabalho livre e a outra no trabalho escravo, uma exitosa e a outra fracassada. Álvaro não conseguiu somente manter, como também aumentar a fortuna herdada dos pais. Leôncio, ao contrário, perde todos os seus bens materiais. A morte de Leôncio, o seu suicídio, é emblemática. Com ela se encerra e se supera o ciclo escravagista que por tanto tempo foi uma nódoa para o Brasil, e abre-se espaço para uma nova era, moderna e civilizada.

Retomando a questão abordada acima sobre a natureza abolicionista de Bernardo Guimarães, podemos concluir que, de fato, o autor não aborda de forma sistemática as injúrias sofridas pelos escravos. Antes, vemos dois casais de jovens apaixonados, Álvaro/ Isaura e Carlos/Rosaura, que veem o seu amor impedido por barreiras sociais. Álvaro, no entanto, havia emancipado os seus escravos antes de conhecer Isaura, o que demonstra que a sua posição a respeito não provém do amor experimentado pela escrava. Ele é antiescravagista por convicção, porque sêlo é sensato e justo. O sistema escravagista já não trazia nenhum beneficio para $o$ desenvolvimento do país, ao contrário permitia que pessoas brancas, como Isaura e Rosaura se tornassem vítima do abuso de seus senhores:

Enquanto houver escravidão, hão de se dar esses exemplos. Uma instituição má produz uma infinidade de abusos, que só poderão ser extintos cortando-se o mal pela raiz (GUIMARÃES, 1981, p. 92).

A abolição não deveria ser gradual, mas sim imediata. Os escravos não precisavam ser preparados para a liberdade porque permaneceriam vinculados aos seus antigos senhores como trabalhadores livres e assalariados. As leis “[...] miseráveis e estúpidas” (GUIMARÃES, 1981, p. 92), tinham que ser repensadas e reformuladas, a mudança, contudo, podia ser iniciada imediatamente através da ação de cada proprietário. Álvaro dá o exemplo. Parece evidente que Bernardo não apoiava uma revolução por parte dos escravos, a abolição deveria ocorrer de forma pacífica e por meios legais. $\mathrm{O}$ autor parece compartir a ideia de Nabuco de que a propaganda política deveria ser dirigida contra uma instituição e não contra pessoas, pois era necessário atacar “[...] o domínio que [elas] exercem e o estado de atraso em que a instituição que representam mantem o país todo" (NABUCO, 2000, p. 14).

Agora, porque uma escrava branca? Bosi opina que a cor branca de Isaura é 
resultado da influência de padrões estéticos europeus (BOSI, 1994, p. 144). Armelim Guimarães discorda. Para ele, a cor da protagonista desempenha uma função essencial no romance, e a decisão de descrever os infortúnios de uma escrava branca foi um mecanismo empregado de forma consciente pelo autor. Segundo ele, a desgraça de uma escrava negra não teria comovido ninguém:

[...] é preciso que a sinhazinha se sinta no lugar da negra e que o senhor desalmado veja sua própria filha debaixo do azorrague do feitor, lá fora, amarrada ao tronco! (GUIMARÃES, 1985, p. 159). [grifo no original]

Para Armelim Guimarães, portanto, a apresentação da heroína como uma escrava branca não faz a obra decair no seu tom abolicionista. Como buscamos expor acima, Bernardo Guimarães aborda vários argumentos do debate abolicionista, toma posição, expõe um modelo a seguir e contribui claramente para a propagação de ideias abolicionistas. Ainda que seja legítima a indagação sobre os motivos que levam Bernardo a narrar a história de duas escravas brancas, os trechos expostos das obras Rosaura: a enjeitada e A escrava Isaura não deixam dúvida respeito à posição do autor em relação à escravidão.

\section{CONSIDERAÇões FINAIS}

Durante o século XIX, o Brasil sofreu importantes mudanças na sua estrutura política e social. Muito se debateu sobre o futuro do país, sobre a forma de governo a ser adotada - República ou Império -, e como o Brasil, agora independente, poderia crescer a aproximar-se aos países-modelos, isto é, aos países europeus. Com a escravidão sendo abolida em todos os países do Hemisfério Leste, não é de se admirar que também essa questão fosse abordada pelos intelectuais brasileiros. Dá-se inicio a um ardente debate e o país se divide entre defensores e opositores da abolição. Nesse contexto são publicadas as obras de Bernardo Guimarães, A Escrava Isaura e Rosaura: a enjeitada. Ambas as obras, de forma mais ou menos evidente, desconstrõem os argumentos dos escravocratas na luta contra a abolição da escravidão, mostrando as falhas e malefícios do sistema. Ademais, o autor busca mostrar que a emancipação é viável e benéfica. A dicotomia escravidão/abolição, imoralidade/humanitarismo, atraso/progresso é modelada literalmente através da oposição Leôncio/Álvaro. A obra de Bernardo Guimarães, portanto, pode ser concebida como um importante documento histórico, pois ela aborda questões centrais do movimento abolicionista e deixa eternizado um quadro das ideias que circularam no século XIX em torno da abolição.

\section{REFERÊNCIAS}

ABREU, J. A. C. D. de. Os abolicionismos na prosa brasileira: de Maria Firmina dos Reis a Machado de Assis. Coimbra. 2013. 472f. Tese (doutorado) - Universidade de Coimbra, Coimbra, 2013. (Disponível em: https://estudogeral.sib.uc.pt/bitstream/10316/23777/1/Os\%20 Abolicionismos\%20na\%20Prosa\%20Brasileira.pdf ; Acesso em 21/10/2014).

ALLPORT, G. Die Natur des Vorurteils. Köln: Kiepenheuer \&Wirsch, 1971. 
ALVES, M. F. Os romancistas da Abolição: representação do escravo e discurso abolicionista nas obras de Bernardo Guimarães e Joaquim Manuel de Macedo. 2012. 165f. Tese (doutorado) -Universidade Federal de Goiás, Goiania, 2012. Disponível em: <http://repositorio.bc.ufg.br/ tede/handle/tde/2333\#preview-link0>. Acesso em: 21 out. 2014.

BÍBLIA, A. T. Gênesis. Português. Bíblia sagrada. Nova tradução na linguagem de hoje. Barueri: Sociedade Bíblica do Brasil, 2000, cap. 9, vers.25.

BOSI, A. História concisa da literatura brasileira. 44a ed. São Paulo: Cultrix, 2007.

BOSI, A. História concisa da literatura brasileira. 37a ed. Cultrix: São Paulo, 1994.

BOSI, A. A dialética da colonização. São Paulo: Companhia das Letras, 1992.

CARVALHO, C. A. Imagensdonegro na literatura brasileira doséculoXIX: uma análise do romance Úrsula, de Maria Firmina dos Reis. Ciências Humanas em Revista. v. 4, n. 2, p. 53-69, dez. 2006.

COSTA, E. V. da: Da Senzala à Colônia. 4. ed. São Paulo: Ed. Unesp, 1997.

COWLING, C. Debating Womanhood, Defining Freedom: the abolition of slavery in 1880s Rio de Janeiro. Gender \& History, [s.I], v. 22, n² 2, p. 284-301, aug. 2010.

FERREIRA, C. L. A questão social no Brasil, 1888-1950. 2010. 46f. ISE - Instituto Superior de Educação da Faculdade Alfredo Nasser, Aparecida de Goiânia, 2010. Disponível em: <https:// de.scribd.com/doc/145636761/A-QUESTAO-RACIAL-NO-BRASIL-1888-1950-CESARLUIZ>. Acesso em: 21 out. 2014.

FIGUEIREDO, L. A. de. Considerações a respeito da escrava Isaura. Alfa. Revista de linguística. v. 13/14, FFCL: Marília, p. 315-323, 1968.

FRANÇA, J. M. C. Imagens do negro na literatura brasileira (1584-1890). São Paulo: Brasiliense, 1998.

GUIMARÃES, B. Rosaura: a enjeitada. [s.l]: Associação de acervos literários biblioteca virtual, 2005. Disponível em: <https://sites.google.com/site/sitedobg/Home/downloads $>$. Acesso em: 22 out. 2014.

GUIMARÃES, B. A escrava Isaura. 10. ed. São Paulo: Ática, 1981. (Série Bom livro).

GUIMARÃES, J. A. B. E. Assim nasceu a Escrava Isaura. A vida boêmia de Bernardo Guimarães. Brasília: Senado Federal. Centro Gráfico, 1985.

LÜSEBRINK, H. J. Von der Geschichte zur Fiktion - die Haitianische Revolution als gesamtamerikanisches Ereignis. In: ZOLLER, R. et.al. Amerikaner wider Willen. Beiträge zur Sklaverei in Lateinamerika und ihren Folgen. Frankfurt am Main: Vervuert Verlag, 1994, p.145-160. 
MACEDO, J. M. As vítimas algozes, [s.l.: s.n.], sem data. Disponível em: <http://www. dominiopublico.gov.br/pesquisa/DetalheObraForm.do?select_action=\&co_obra=2134>. Acesso em: 22 out. 2014.

MARTINS, W. História da inteligência brasileira. Volume II (1794-1855). São Paulo: Cultrix, Edição da universidade de São Paulo, 1977-78.

MASSAUDE, M. A literatura brasileira através dos textos. 5. ed. São Paulo: Cultrix, 1977.

MOURA, M. de S. A dupla marginalidade de Cruz e Souza. Frente à sociedade branca e à racionalidade positivista. 1997. 127f. Dissertação (Mestrado) - Instituto de Letras, Universidade do Estado do Rio de Janeiro, Rio de Janeiro, 1997.

NABUCO, J. O abolicionismo. São Paulo: Publifolha, 2000. Disponível em: <http://www. dominiopublico.gov.br/download/texto/bv000127.pdf>. Acesso em: 18 abr. 2014.

OLÍMPIO, F. P. O Mulato: uma reflexão sobre questões identitárias, no entrecruzamento entre história cultural e literatura. Em Tempo de Histórias - Publicação do Programa de PósGraduação em História, PPG-HIS/UnB, n.11, Brasília, 2007, p. 59-76.

ORTIZ, F. Hampa afro-cubana. Los negros esclavos. Habana: La universal, 1916.

PATROCINIO, J. Campanha Abolicionista. Coletânea de artigos. Rio de Janeiro: Fundação Biblioteca Nacional, Dep. Nacional do Livro, 1996.

RABASSA, G. O negro na ficção brasileira. Tradução Ana Maria Martins. Rio de Janeiro: Tempo Brasileiro, 1965.

SAYERS, R. S. The Negro in Brazilian Literature. Denver: The Bell Press, 1956.

SILVEIRA, D. M. Gênero e escravidão em Bernardo Guimarães. VI Encontro Escravidão e Liberdade no Brasil Meridional, UFSC: Santa Catarina, p. 1-13, 15-18 Maio de 2013.

SKIDMORE, T. E. Black into White. Race and Nationality in Brazilian Thought. New York: Oxford University Press, 1974.

VENTURA, R. Escritores e mestiços em um País Tropical. Literatura, historiografia e ensaísmo no Brasil. Nürnberg: Wilhelm Fink Verlag, 1987.

VIGNAUX, H. Marginación de negros y mulatos en el Nuevo Reino de Granada (siglo XVII). In: CARBONETTI, Adrian. et. al. (eds.). De sujetos, definiciones y fronteras. Ensayos sobre disciplinamiento, marginación y exclusión en América. De la colonia al siglo XX. San Salvador de Jujuy: Ferreyra Editor, 2002, p. 17-52. 